\title{
Dynamic Wind-Tunnel Testing of a Sub-Scale Iced S-3B Viking
}

Sam Lee

ASRC Aerospace Corporation, Cleveland, Ohio

Billy Barnhart

Bihrle Applied Research, Inc., Hampton, Virginia

Thomas P. Ratvasky

Glenn Research Center, Cleveland, Ohio 


\section{NASA STI Program . . . in Profile}

Since its founding, NASA has been dedicated to the advancement of aeronautics and space science. The NASA Scientific and Technical Information (STI) program plays a key part in helping NASA maintain this important role.

The NASA STI Program operates under the auspices of the Agency Chief Information Officer. It collects, organizes, provides for archiving, and disseminates NASA's STI. The NASA STI program provides access to the NASA Aeronautics and Space Database and its public interface, the NASA Technical Reports Server, thus providing one of the largest collections of aeronautical and space science STI in the world. Results are published in both non-NASA channels and by NASA in the NASA STI Report Series, which includes the following report types:

- TECHNICAL PUBLICATION. Reports of completed research or a major significant phase of research that present the results of NASA programs and include extensive data or theoretical analysis. Includes compilations of significant scientific and technical data and information deemed to be of continuing reference value. NASA counterpart of peer-reviewed formal professional papers but has less stringent limitations on manuscript length and extent of graphic presentations.

- TECHNICAL MEMORANDUM. Scientific and technical findings that are preliminary or of specialized interest, e.g., quick release reports, working papers, and bibliographies that contain minimal annotation. Does not contain extensive analysis.

- CONTRACTOR REPORT. Scientific and technical findings by NASA-sponsored contractors and grantees.
- CONFERENCE PUBLICATION. Collected papers from scientific and technical conferences, symposia, seminars, or other meetings sponsored or cosponsored by NASA.

- SPECIAL PUBLICATION. Scientific, technical, or historical information from NASA programs, projects, and missions, often concerned with subjects having substantial public interest.

- TECHNICAL TRANSLATION. Englishlanguage translations of foreign scientific and technical material pertinent to NASA's mission.

Specialized services also include creating custom thesauri, building customized databases, organizing and publishing research results.

For more information about the NASA STI program, see the following:

- Access the NASA STI program home page at http://www.sti.nasa.gov

- E-mail your question to help@sti.nasa.gov

- Fax your question to the NASA STI Information Desk at 443-757-5803

- Phone the NASA STI Information Desk at 443-757-5802

- Write to: STI Information Desk NASA Center for AeroSpace Information 7115 Standard Drive Hanover, MD 21076-1320 
NASA/TM-2012-217684

AIAA-2010-7986

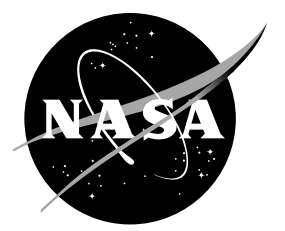

\section{Dynamic Wind-Tunnel Testing of a Sub-Scale Iced S-3B Viking}

Sam Lee

ASRC Aerospace Corporation, Cleveland, Ohio

Billy Barnhart

Bihrle Applied Research, Inc., Hampton, Virginia

Thomas P. Ratvasky

Glenn Research Center, Cleveland, Ohio

Prepared for the

Atmospheric and Space Environments Conference

sponsored by the American Institute of Aeronautics and Astronautics

Toronto, Ontario, Canada, August 2-5, 2010

National Aeronautics and

Space Administration

Glenn Research Center

Cleveland, Ohio 44135 
Level of Review: This material has been technically reviewed by technical management.

Available from

NASA Center for Aerospace Information

7115 Standard Drive

Hanover, MD 21076-1320
National Technical Information Service 5301 Shawnee Road Alexandria, VA 22312

Available electronically at http://www.sti.nasa.gov 


\title{
Dynamic Wind-Tunnel Testing of a Sub-Scale Iced S-3B Viking
}

\author{
Sam Lee \\ ASRC Aerospace Corporation \\ Cleveland, Ohio 44135 \\ Billy Barnhart \\ Bihrle Applied Research, Inc. \\ Hampton, Virginia 23666 \\ Thomas P. Ratvasky ${ }^{1}$ \\ National Aeronautics and Space Administration \\ Glenn Research Center \\ Cleveland, Ohio 44135
}

\begin{abstract}
The effect of ice accretion on a 1/12-scale complete aircraft model of S-3B Viking was studied in a rotary-balance wind tunnel. Two types of ice accretions were considered: ice protection system failure shape and runback shapes that form downstream of the thermal ice protection system. The results showed that the ice shapes altered the stall characteristics of the aircraft. The ice shapes also reduced the control surface effectiveness, but mostly near the stall angle of attack. There were some discrepancies with the data with the flaps deflected that were attributed to the low Reynolds number of the test. Rotational and forced-oscillation studies showed that the effects of ice were mostly in the longitudinal forces, and the effects on the lateral forces were relatively minor.
\end{abstract}

\subsection{Introduction}

An S-3B Viking aircraft was considered for possible use at NASA Glenn Research Center for use in icing research. This type of aircraft had never been used for icing research, so its flight characteristics in an icing environment were unknown. In order to gain insight into the icing effects prior to conducting icing research flights, this experimental effort was initiated to determine the aircraft's iced aerodynamic characteristics.

The effort consisted of 4 parts:

(1) Determine the ice shapes to test.

(2) Test the ice shapes on a subscale complete aircraft model in a rotary balance wind tunnel.

(3) Use the wind tunnel data to develop iced aircraft flight simulation models.

(4) Refine and validate the flight simulation models through flight testing.

This method was successfully performed during research efforts for the DHC-6 Twin Otter (Refs. 1 to 3) and a Cessna business jet (Refs. 4 to 6).

It was decided to test two ice accretion shapes. The first was the shape that would form on the aircraft when the ice protection system has failed (failure shape). The second was the runback shape that forms downstream of the leading edge when the aircraft's thermal ice protection system becomes overwhelmed. The failure shape geometry was obtained using LEWICE simulation (Ref. 7). The runback shape geometry was simulated with simple aerodynamically equivalent shapes using lessons learned from previous research efforts (Refs. 4 and 5). This paper details the testing of the two ice shapes in a rotary balance wind tunnel in order to obtain the aerodynamic data needed for the simulation model development.

${ }^{1}$ Distinguished Research Associate. 


\section{Nomenclature}

$\begin{array}{ll}b & \text { aircraft span } \\ c & \text { aircraft chord } \\ C_{l} & \text { aircraft rolling moment coefficient } \\ C_{L} & \text { aircraft lift coefficient } \\ C_{L, m a x} & \text { aircraft maximum lift coefficient } \\ C_{m} & \text { aircraft pitching moment coefficient } \\ \text { LWC } & \text { liquid water content } \\ \text { MVD } & \text { median volumetric diameter } \\ \text { OAT } & \text { outside air temperature } \\ p & \text { aircraft roll rate } \\ q & \text { aircraft pitch rate } \\ q_{\infty} & \text { freestream dynamic pressure } \\ R e & \text { Reynolds number } \\ V & \text { airspeed } \\ \alpha & \text { aircraft angle of attack } \\ \delta e & \text { elevator deflection angle } \\ \delta f & \text { flap deflection angle } \\ \Omega & \text { rotational rate about the velocity vector }\end{array}$

\subsection{Experimental Methods}

The test was conducted in the Bihrle Applied Research Large Amplitude Multi-Purpose (LAMP) facility in Neuberg a.d. Donau, Germany. It is an open circuit vertical wind tunnel with a 10-ft diameter circular test section. It is capable of static, rotational, and forced-oscillation measurements. The forces were measured by a six-component strain-gauge balance affixed to the end of a sting and mounted inside the aircraft model. The tests were conducted at a dynamic pressure of $2 \mathrm{psf}$, which corresponded to a model $R e=0.10$ million. Shown in Figure 1 is the 1/12-scale S-3B model mounted in the test section. The model was constructed of fiberglass, balsa, and plywood from a 3D CAD data of the aircraft. The model was equipped with moveable control surfaces (aileron, rudder, elevator, flaps, spoilers and speed brakes) as well as extended landing gear. A preliminary conceptual model of icing research instrument cluster pod was also attached to each wing stores pylon. The ice shapes chosen for testing consisted of the following:

- Ice protection system failure

- Runback ice shapes that form downstream of thermal anti-ice system

The failure shape geometry was generated using LEWICE 3D using the flight conditions shown in Table 1 . The condition shown below was chosen to represent a typical severe icing encounter during a research flight. LEWICE 3D generates ice shapes in series of 2D slices at various spanwise locations. These were then lofted to form three-dimensional geometry. Ice shapes geometries were obtained for wing and horizontal and vertical stabilizers. These shape were then geometrically scaled from the fullscale to $1 / 12$ scale. Previous experimental studies have shown that airfoils with large leading edge ice accretions are insensitive to Reynolds number effects, and simply scaling the ice shapes geometrically for subscale testing produces satisfactory results (Refs. 8 and 9). The methodology to develop the failure ice 
shape geometry with LEWICE 3D is explained in more detail by Bidwell (Ref. 7). For the wind tunnel testing, the ice shapes were constructed using a laser sintering rapid prototype process and placed on the leading edge of wing as well as horizontal and vertical stabilizer as shown in Figure 2. Figures 2(a) and 2(b) show the LEWICE generated ice slices on the wing and horizontal stabilizer. Figures 2(c) and 2(d) show the lofted 3D ice shapes on the aircraft model.

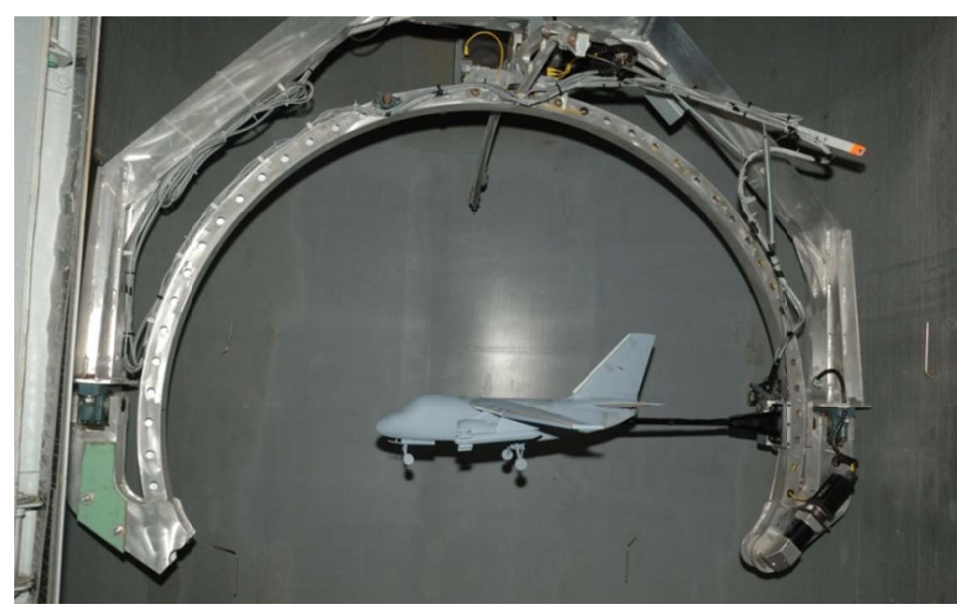

Figure 1.-S-3B Viking model in LAMP test section.

TABLE 1.-ICING CONDITIONS FOR FAILURE SHAPE

\begin{tabular}{|c|c|c|c|c|c|}
\hline Aircraft $\alpha$ & Airspeed & LWC & MVD & OAT (C) & Accretion time \\
\hline $8^{\circ}$ & $194 \mathrm{kts}$ & $0.5 \mathrm{~g} / \mathrm{m}^{3}$ & $20 \mu \mathrm{m}$ & $-8{ }^{\circ} \mathrm{C}$ & $45 \mathrm{~min}$. \\
\hline
\end{tabular}

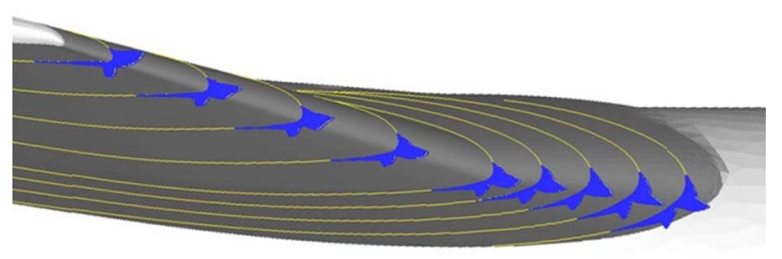

(a)

(b)

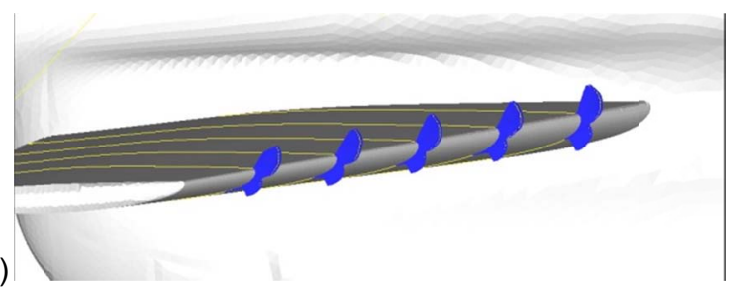

(c)

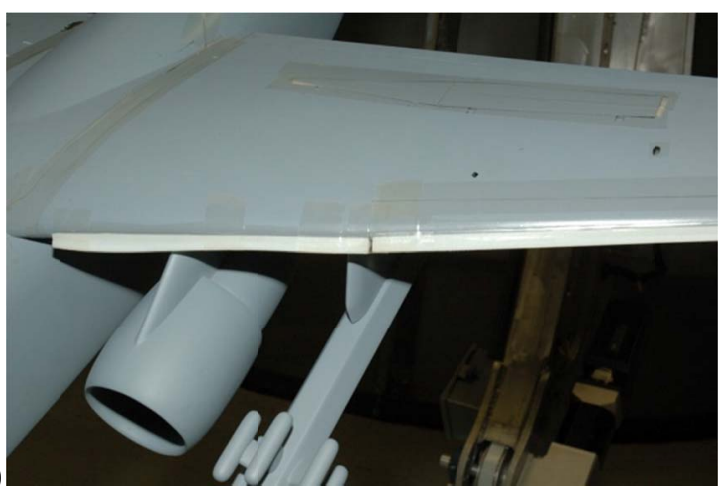

(d)

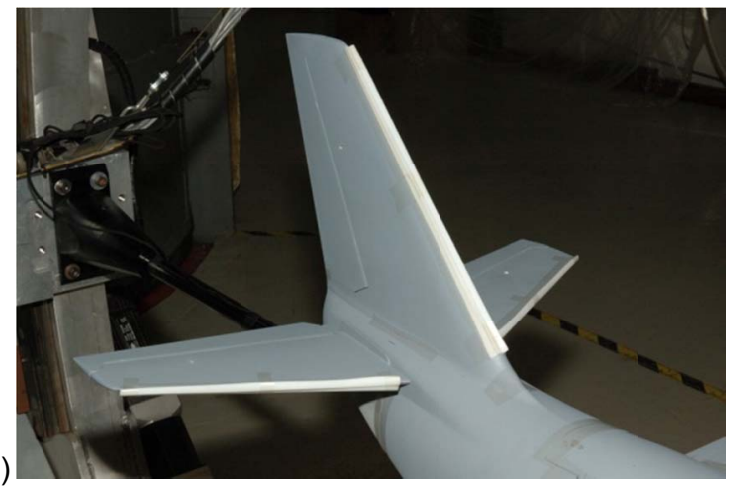

Figure 2.-Failure-shape configuration. (a) LEWICE sections on wing. (b) LEWICE sections on horizontal stabilizer. (c) Wing. (d) Tail. 

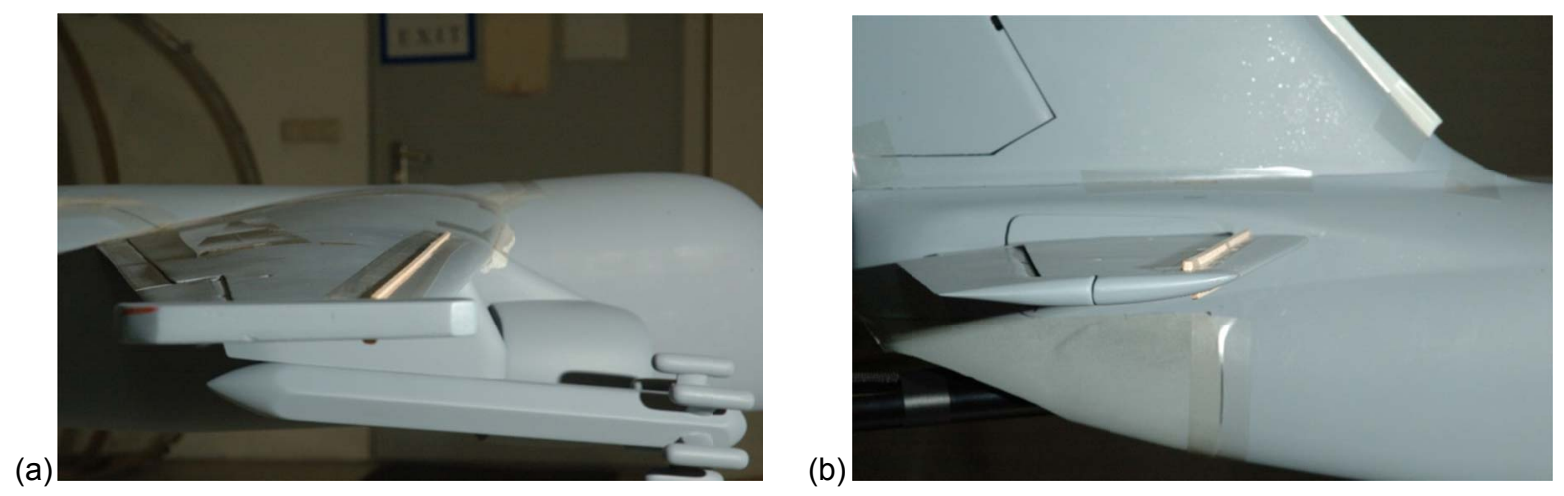

Figure 3.-Runback shape configuration. (a) Wing. (b) Tail.

The runback shape geometries used were the scaled simple geometry shapes that would be aerodynamically equivalent to the full-scale ice shapes. The shapes were chosen based on experience gained in previous efforts. The runback shapes were only applied behind the ice protected portions of the wing and tail since they are not expected to form behind unheated part of the aircraft. On the wing, $1 / 16$ in. square balsa strips were applied to the upper surface and $1 / 8$ in. square balsa strips were applied to the lower surface. On the horizontal stabilizer, 3/32 in. balsa strips were placed on the upper surface and $1 / 16$ in. square balsa strips were placed on the lower surface. The leading edge of the runback shapes were placed at the aft end of the leading edge ice protection system. The failure shape geometry was placed on the inboard portion of the wing and the entire vertical stabilizer since they were not ice protected. Figure 3 shows the runback shape configuration.

\subsection{Results and Discussion}

As stated previously in the experimental section, all of the measurements were taken at a dynamic pressure of $2 \mathrm{psf}$, resulting in the aircraft $R e=0.10$ million. The data from the wind-tunnel tests at such low Reynolds number cannot usually be directly used in the flight simulation model. For the clean aircraft, the lower Reynolds number results in decreased stall angle of attack and maximum lift coefficient. Figure 4 shows the lift curve from a previous study (Ref. 4) with another aircraft in the LAMP facility. The LAMP data showed a significantly lower stall angle of attack and maximum lift coefficient when compared to the flight Reynolds number data obtained from the aircraft manufacturer. This required a "shift" in the lift curve of the LAMP data, which resulted in a lift curve that compared very favorably to the flight Re data, including the stall and post-stall characteristics. Consequently, all of the clean data were shifted in similar manner in order to be used in the flight simulation model. Iced configurations required shifting of the data to varying degrees, depending on the type of ice shape. The failure shapes did not require any shifting of the data, as it was shown not to have any Reynolds number effect (Ref. 5).

Other ice shapes such as leading edge roughness and runback shapes did require some shifting of the data, based on results of Reynolds number scaling work performed prior to the LAMP test.

\subsection{Lift}

Figure 5 shows the effect of the ice shapes on the S-3B Viking model aircraft lift coefficient. With the clean configuration and zero flap deflection (Fig. 5(a)), the aircraft stalled at $\alpha=12^{\circ}$ with a maximum lift coefficient of 0.9. With the failure shape, a well-defined stall was not present. Instead, the lift increased linearly with angle of attack, although non-linearly after $\alpha=6^{\circ}$. The failure configuration had lower lift when compared to the clean aircraft from $\alpha=0$ to $13^{\circ}$. With the runback configuration, the lift curve was similar to that of the failure shape from $\alpha=0$ to $13^{\circ}$. However, there was a defined stall present at 


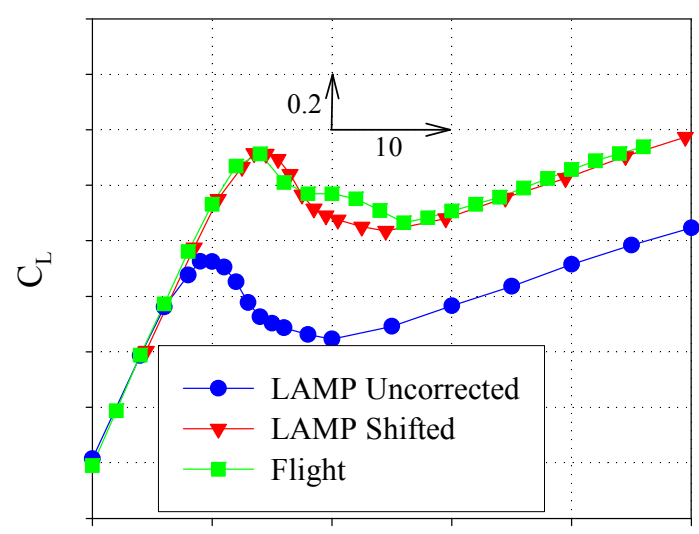

(a)

$\alpha(\operatorname{deg})$

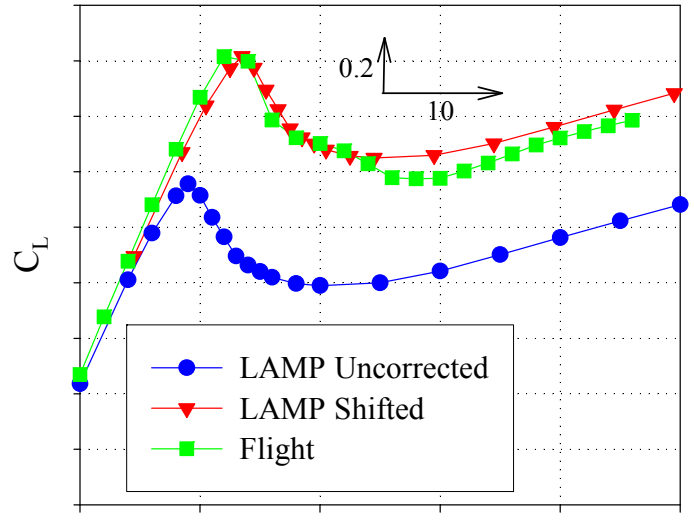

(b)

$\alpha(\operatorname{deg})$

Figure 4.-Comparison of airframe manufacturer's and LAMP lift coefficient data from a previous study. (a) $\delta f=0^{\circ}$. (b) $\delta f=20^{\circ}$.

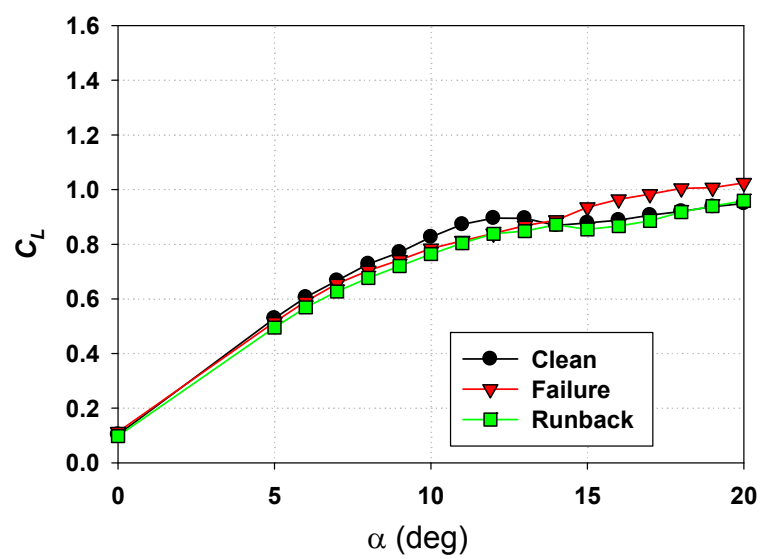

(a)

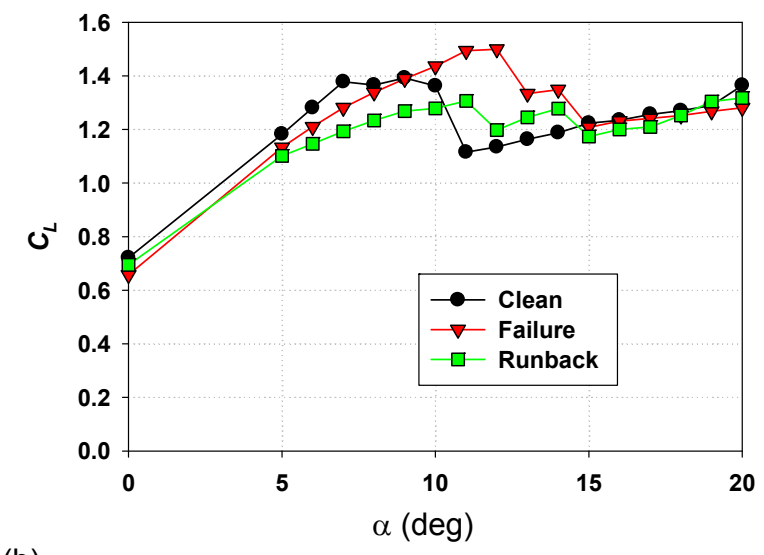

(b)

Figure 5.-Effect of ice shape on lift. (a) $\delta f=0^{\circ}$. (b) $\delta f=25^{\circ}$.

$\alpha=14^{\circ}$, with a local maximum lift value of 0.86. It may appear from Figure 5(a) that these ice shapes did not significantly degrade the aircraft lift curve. However, these test were conducted at Reynolds number of approximately 0.10 million, whereas the full scale aircraft typically operates at 20 million. Thus, in order to apply the data to full-scale flight simulation model, the clean lift curve would be expanded to give a higher maximum lift and stall angle of attack, as shown in Figure 4. Every iced aerodynamics studies have shown that large leading edge iced configurations are Reynolds number insensitive. So, when applied to a full-scale aircraft, the differences between the clean and failure iced configurations would be much greater.

Figure 5(b) shows the lift curves with the flaps (both leading and trailing edge) deflected at $25^{\circ}$. As expected, deploying the flap resulted in higher lift for both clean and iced configurations. On the clean model, it increased the $C_{L, \max }$ from 0.90 to 1.38 and decreased the stall angle of attack from 12 to $7^{\circ}$. The maximum lift coefficient of the failure shape configuration was increased to 1.5 , and the stall angle of attack was $12^{\circ}$. These were much higher than the clean model, which was not expected. The runback shape configuration had a $C_{L, \max }$ of 1.30 with a stall angle of attack of $11^{\circ}$. It was not clear why the failure configuration had such a high $C_{L, \max }$ when the flap was deployed. 


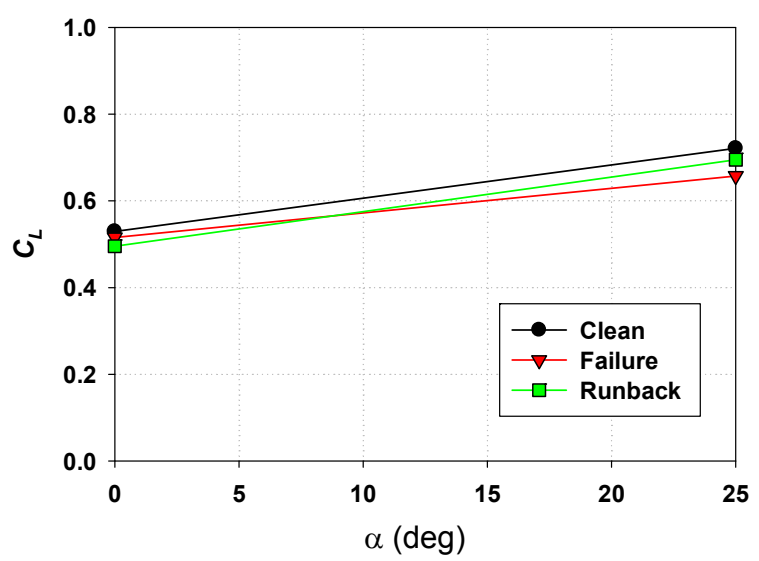

(a)

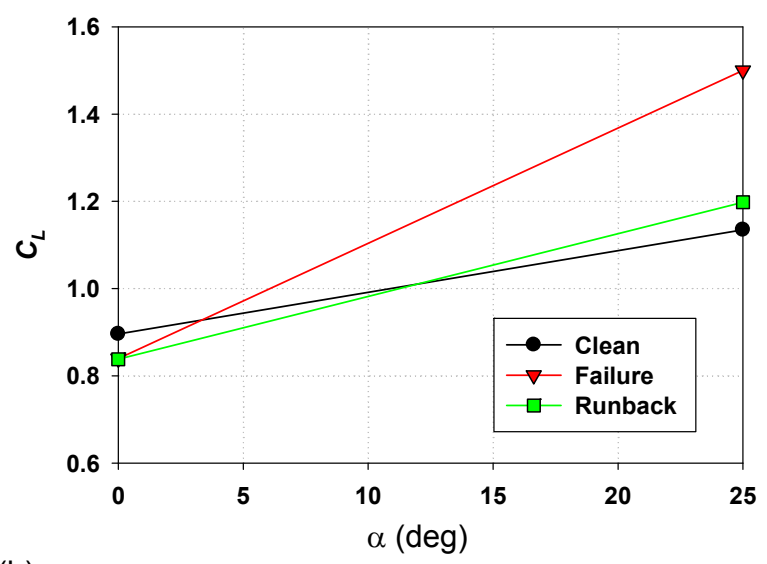

(b)

Figure 6.-Effect of ice shape on flap effectiveness. (a) $\alpha=0^{\circ}$. (b) $\alpha=12^{\circ}$.

The unexpected effect of flap deflection is better illustrated in Figure 6, which shows the effect of ice shapes on flap effectiveness. The figure shows the aircraft lift coefficient verses flap deflection angles at constant aircraft angles of attack. Figure 6(a) shows the flap effectiveness at $\alpha=0^{\circ}$ (which is in the linear range of the aircraft lift curve), and Figure 6(b) shows the flap effectiveness at $\alpha=12^{\circ}$ (which is at the stall angle of attack of the clean aircraft). Figure 6(a) shows that in the linear range of the lift curve, the ice shapes had very little effect on the flap effectiveness, with the failure shape configuration showing a slightly reduce values, as indicated by its slope. Figure 6(b) shows that at for the clean aircraft, the flap effectiveness at stall angle of attack was unchanged from the linear range of the lift curve. However, with the failure shape configuration, the flap was three times more effectiveness in increasing lift at $\alpha=12^{\circ}$ than the clean configuration. For the runback shape configuration, it was 1.5 times more effective.

One explanation for this anomaly is that the ice shapes on the wing are helping the boundary layer remain attached to the wing when the flaps are deployed. Usually, ice shapes on aircraft wing causes the boundary layer to separate from the wing and stall at a lower angle of attack. However, it appears that at this low Reynolds number, the opposite may be happening. In the previous research efforts with the Twin Otter and the Cessna business jet, this behavior was not observed. However, these aircraft only had trailing edge flaps and not leading edge flaps. Because a Reynolds number and geometric scaling studies were not performed on the S-3B wing panel (unlike in previous efforts), the exact cause of this behavior could not be determined.

\subsection{Pitching Moment}

Figure 7 shows the effect of the ice shapes on the S-3B Viking model aircraft pitching moment. On the clean aircraft, the pitching moment coefficient decreased (i.e., more nose down) linearly with angle attack at angles of attack between 0 and $11^{\circ}$. At $\alpha=11^{\circ}$, there was an abrupt nose up pitching moment as the aircraft stalled. Both of the ice shape configurations showed more positive pitching moment coefficient (when compared to the clean model) at angles of attack between $5^{\circ}$ and stall. The sudden nose up pitching moment on the failure configuration did not occur until $\alpha=14$ and $12^{\circ}$ for the failure and runback shapes, respectively. These corresponded to breaks in the lift curve slopes on Figure 5(a), indicating the angles of attack where the aircraft stalled. The break in the pitching moment coefficient was more gradual with the runback configuration than that of the clean aircraft and failure configuration, indicating a softer, more gradual stall process. 


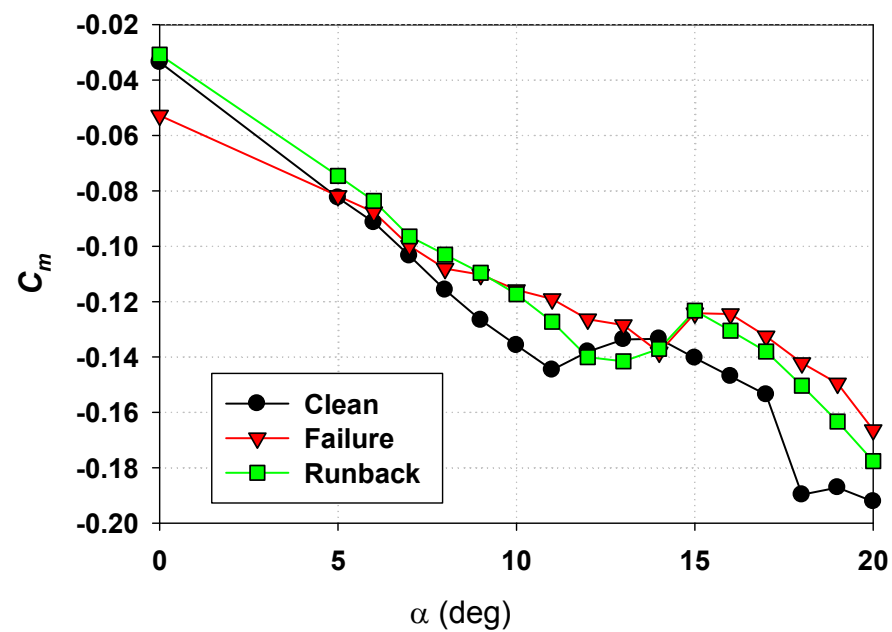

Figure 7.-Effect of ice shape on pitching moment.

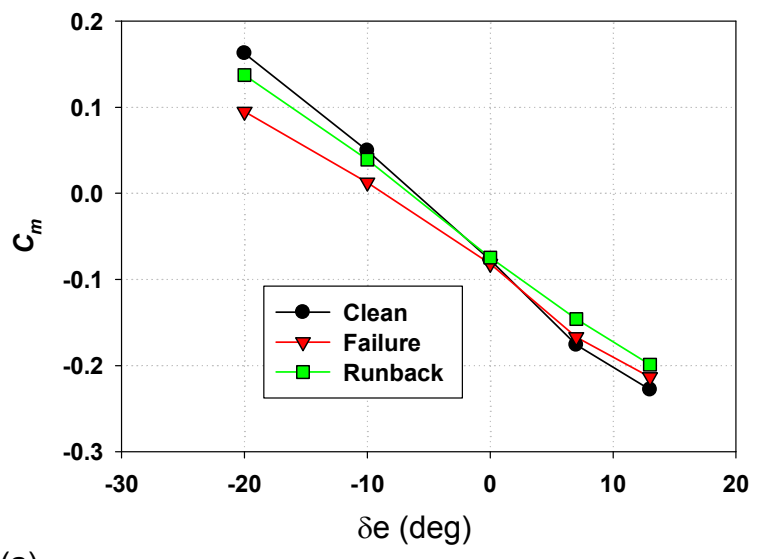

(a)

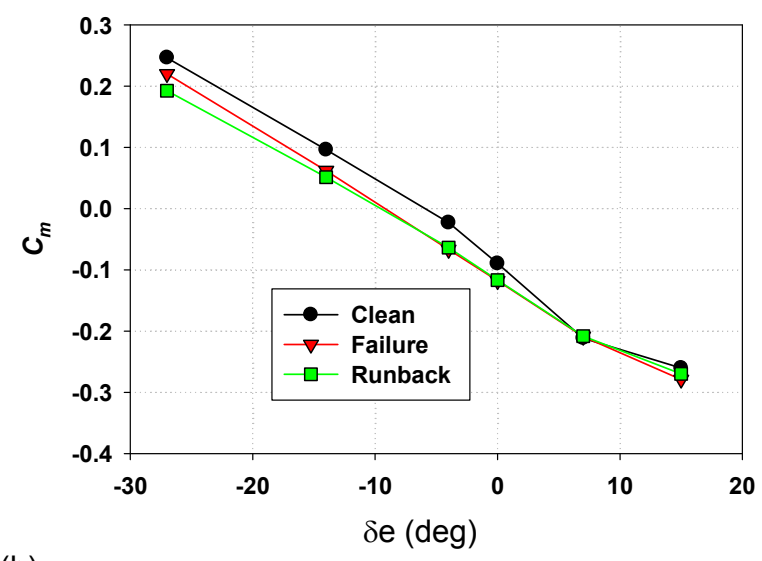

(b)

Figure 8.-Effect of ice shape on elevator effectiveness. $\alpha=5^{\circ}$. (a) $\delta f=0^{\circ}$. (b) $\delta f=25^{\circ}$.

Figure 8 shows the effect of ice shapes on the elevator effectiveness, or the ability of the elevators to change the aircraft pitching moment. Figure 8(a) shows the aircraft pitching moment verses elevator deflection angle with the $\delta f=0^{\circ}$, and Figure 8(b) shows the pitching moment verses elevator angle at $\delta f=25^{\circ}$. The elevator deflection angles are different in Figures 8(a) and 8(b) because the S-3 has different elevator deflection range at different flap settings. Both of the figures are at $\alpha=5^{\circ}$, which was well before stall. Figure 8 shows that there was a nearly linear relationship between the aircraft pitching moment and the elevator deflection angle. Figure 8(a) shows that ice shapes resulted in a slightly decreased elevator effectiveness (indicated by slightly reduced magnitude of $C_{m}-\delta e$ slope) for $\delta f=0^{\circ}$. At $\delta f=25^{\circ}$, all three ice configurations exhibited similar elevator effectiveness.

Figure 9 shows the effect of ice shapes on the pitch authority. It shows the change in the pitching moment the aircraft is able to obtain with full elevator deflection at given lift coefficient. It clearly shows that the presence of ice shape shifted the curves to the left, indicating a reduction in the flight envelope. 


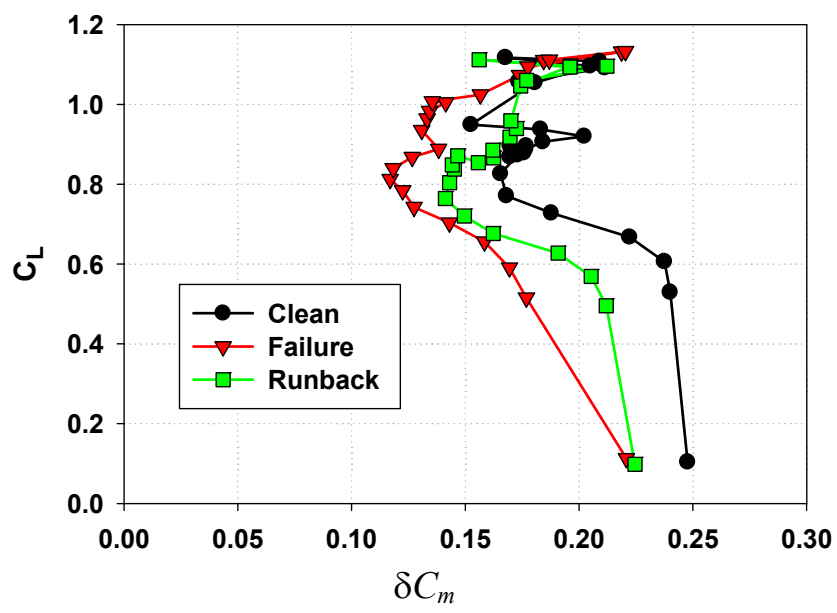

Figure 9.-Effect of ice shape on pitch authority. Maximum elevator deflection.

\subsection{Rolling Moment}

Figure 10 shows the effect of ice shapes on the S-3B Viking model aircraft rolling moment. On the clean aircraft, there was a sudden roll off at $\alpha=11^{\circ}$, as it stalled. With the failure shape configuration, the roll off was delayed until $\alpha=14^{\circ}$ and was not as severe. With the runback configuration, the roll off started at $\alpha=12^{\circ}$, and it was even more severe than the clean configuration.

Figure 11 shows the effect of ice shapes on the aircraft roll authority. It shows the change in the rolling moment the aircraft if able to generate with full aileron deflection at a given lift coefficient. On the clean aircraft, there was a reduction in the roll authority occurring at $C_{L}=0.35$ but it was gradual until $C_{L}=0.82$, at which there was a rapid decrease in the roll authority. The initial gradual reduction in the roll authority may be due to the flow starting to separate over the aileron. The rapid decrease that occurred at higher lift values was likely due to the wing stall. Similar behavior was observed with the two iced configurations. With the failure shape, the roll authority was similar to that of the clean aircraft at low lift values. However, at $C_{L}$ values between 0.7 and 0.9 , it exhibited lower roll authority than the clean aircraft. However, at $C_{L}>0.90$, both clean and failure configuration wing was stalled and showed similar roll authority. When the runback shape configuration was installed, the aircraft exhibited reduced roll authority even at low lift values and continued up to stall. It is important to keep in mind that for the simulation of a full scale aircraft, the clean values would be shifted as discussed above, thus creating an even larger decrease in roll authority with the failure and runback shapes compared to the clean aircraft.

\subsection{Rotational Data}

The effects of the icing on the rotational characteristics were mostly observed in the stall region due to the differences in their stall characteristics and their effects on the rotational rolling moment coefficient. Below stall, there was little or no influence of the ice condition. Figure 12(a) shows that at $\alpha=5^{\circ}$ (well before stall), the clean and iced aircraft rotational characteristics were nearly identical. The differences were observed near stall angles of attack, as shown in Figure 12(b). The differences were small and likely due to different stall characteristics. At angle of attack well past stall (Fig. 12(c)) changes in the rotational rates did not affect the rolling moment for both clean and iced configurations. The effect of ice conditions on rotational yawing moment were observed in the same angle of attack region as roll, but were smaller and of less importance. 


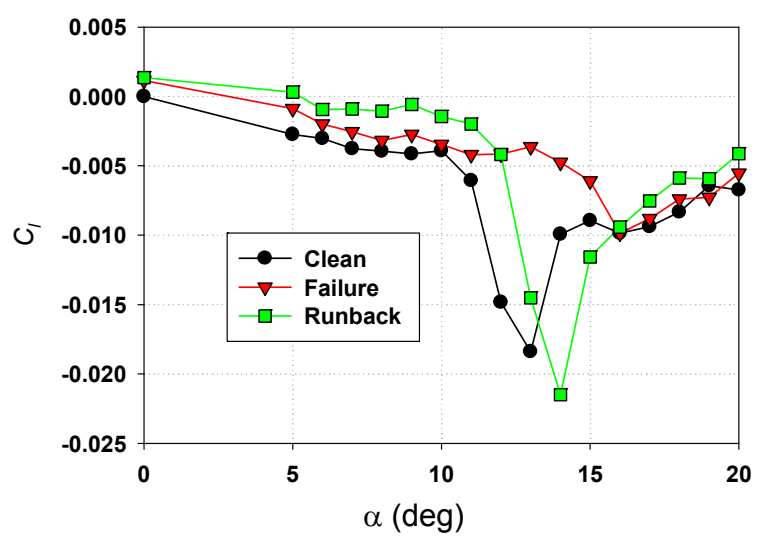

Figure 10.-Effect of ice shape on rolling moment.

(a)

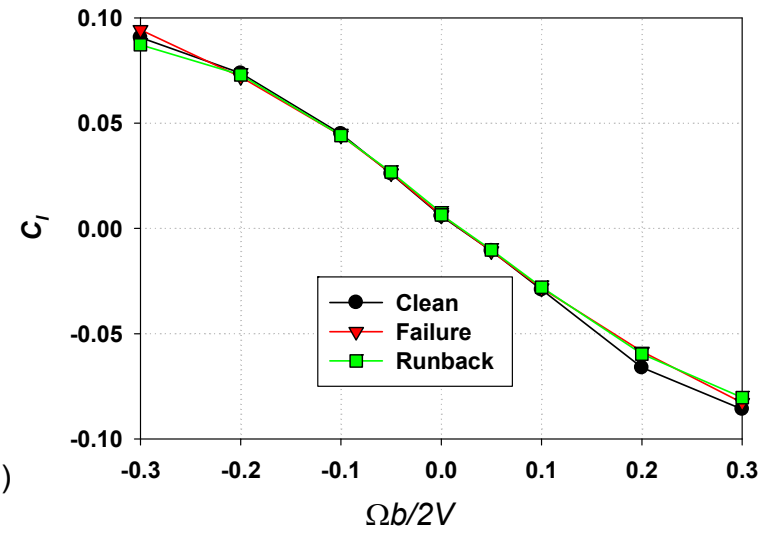

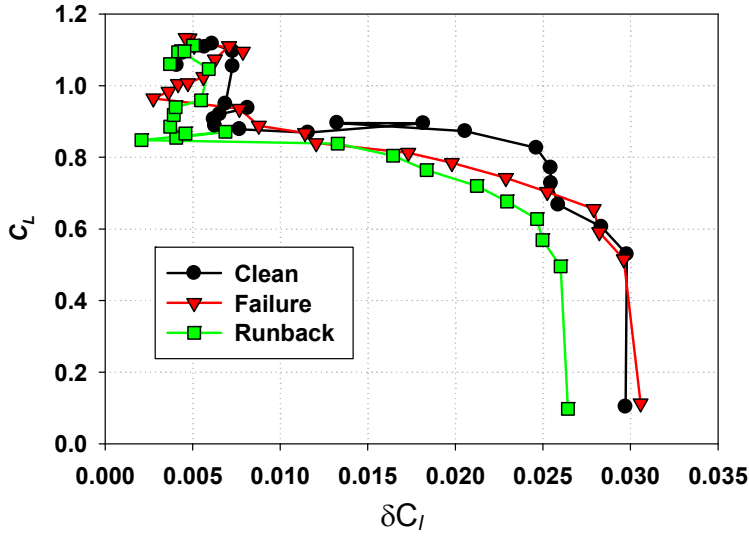

Figure 11.-Effect of ice shape on roll authority.

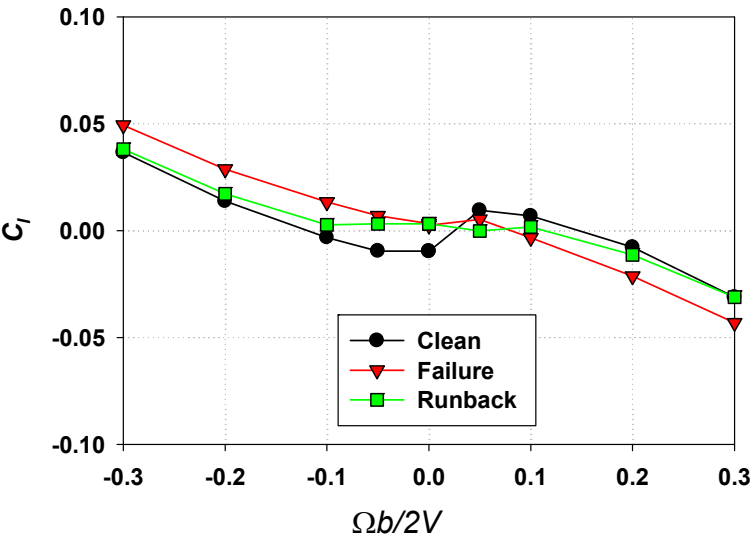

(c)

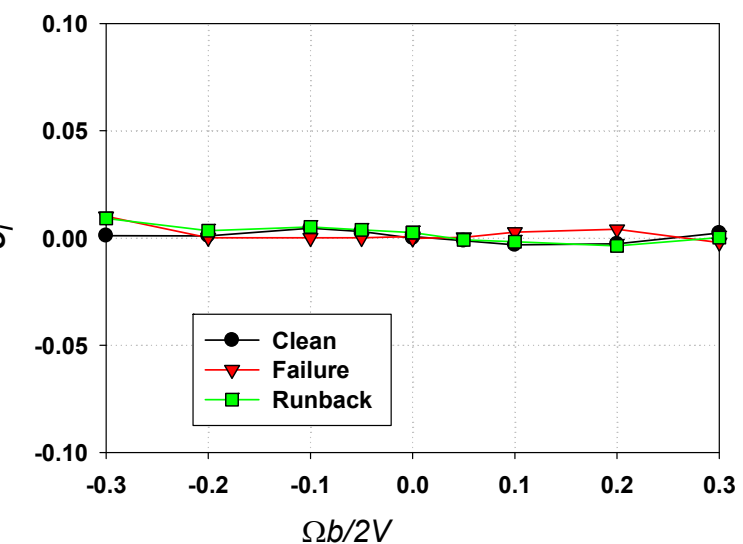

Figure 12.-Effect of ice shape on rotational rolling moment. (a) $\alpha=5^{\circ}$. (b) $\alpha=12^{\circ}$. (c) $\alpha=20^{\circ}$. 


\subsection{Forced Oscillation}

Forced-oscillation tests were performed about all three body axis for the aircraft. The effect of ice shapes on the forced-oscillation data was generally small and occurred mostly in the stall region, which was similar to what was observed in the rotational data.

Figure 13 shows the effect of roll oscillation on the rolling moment. Figure 13(a) shows that ice shapes had very little effect at $\alpha=5^{\circ}$. The only differences observed were near stall angle of attack, as shown in Figure 13(b). Like the rotational data, the effects of ice shapes were small. Figure 14 shows the effect of pitch oscillation on the pitching moment. The effects were very small for both pre-stall (Fig. 14(a)) and stall (Fig. 14(b)) angles of attack. Analysis of other forced-oscillation data showed similar trend of ice shapes having little effect when compared to the clean aircraft.
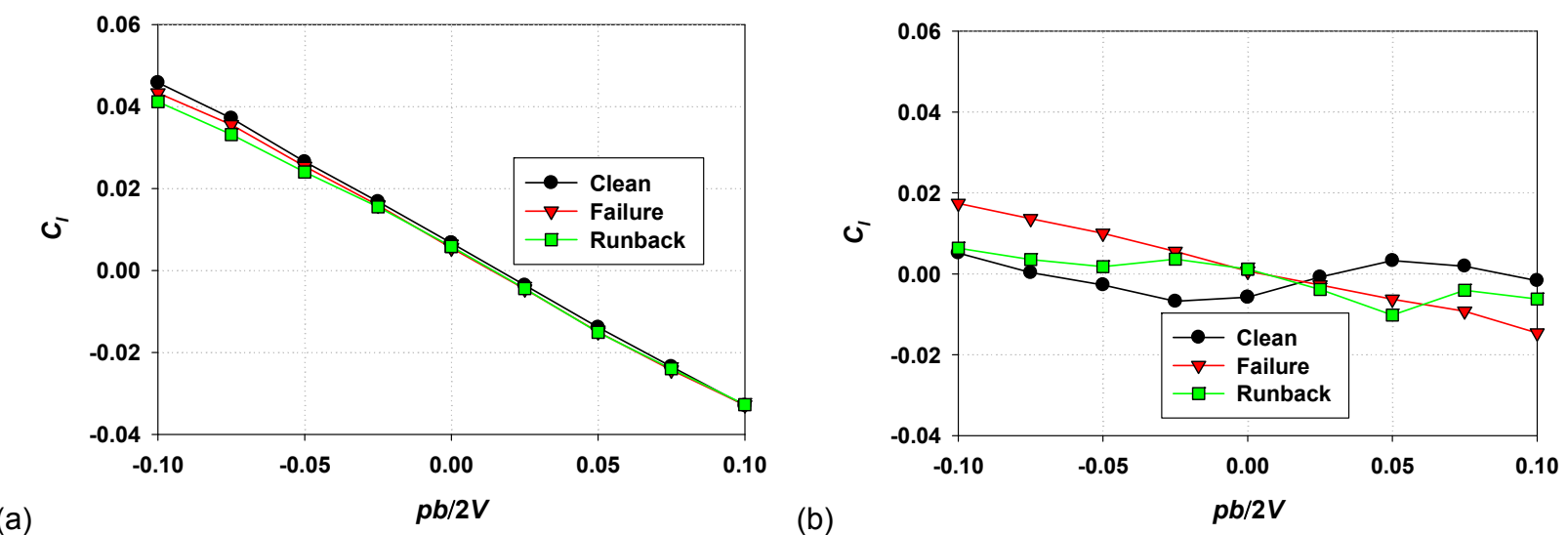

Figure 13.-Effect of ice shape on forced-oscillation rolling moment. (a) $\alpha=5^{\circ}$. (b). $\alpha=12^{\circ}$.
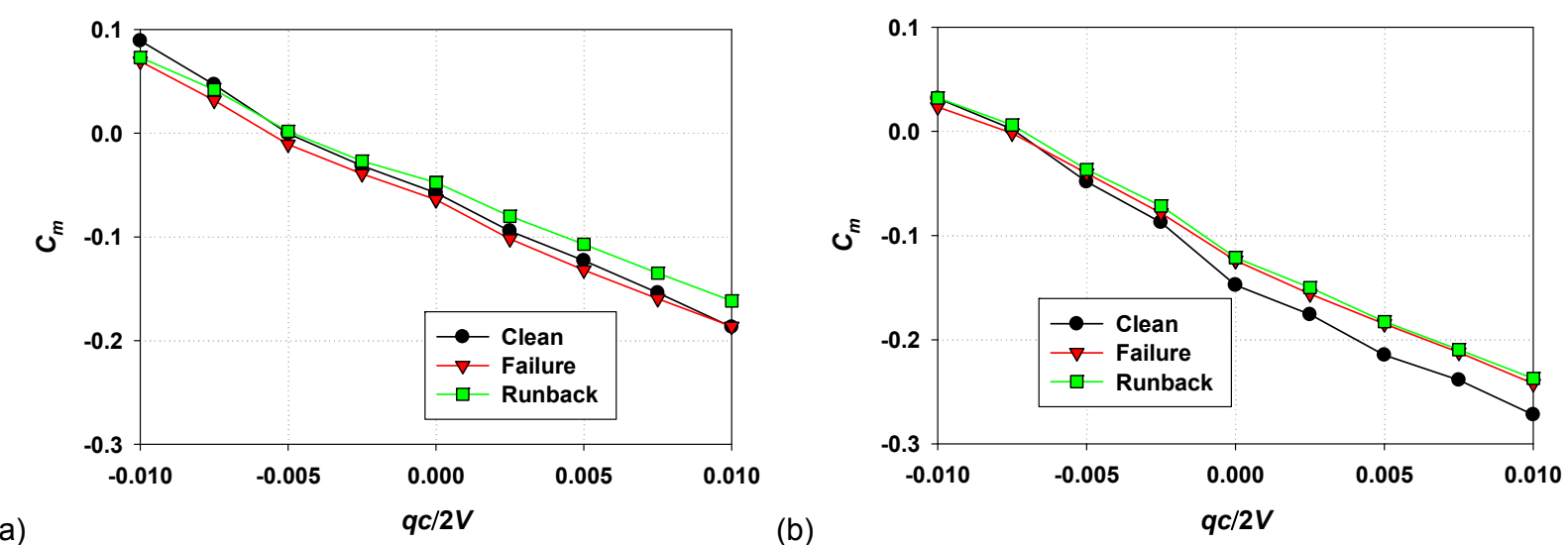

Figure 14.-Effect of ice shape on forced-oscillation pitching moment. (a) $\alpha=5^{\circ}$. (b). $\alpha=12^{\circ}$. 


\subsection{Conclusions}

Wind tunnel measurements of an iced 1/12-scale complete aircraft model of an S-3B Viking were made in a rotary-balance wind tunnel to obtain data for iced-aircraft flight simulation models. Two types of ice accretions were tested: ice protection system failure shape and runback shape that forms downstream of the thermal ice-protection system.

The iced configuration did not severely degrade the aircraft performance when compared to the sub-scale clean configuration. This was expected because of the low Reynolds number of this test. The clean aircraft at the test Reynolds number would have substantially lower maximum lift coefficient and stall angle of attack than at flight Reynolds number. However, the numerous previous tests have shown that airfoils with large leading edge ice shapes are relatively unaffected by Reynolds number variation. Thus, the iced performance values obtained in the subscale test would be similar to the full-scale Reynolds number values. However, this would need to be validated by a full-scale test (i.e., high Reynolds number wind tunnel or flight test).

The data with the flaps deflected at $25^{\circ}$ showed the failure ice shape configuration with a much higher $C_{L, \max }$ than the clean configuration. This was not expected and was speculated to be an artifact of the low Reynolds number of this test. Because a Reynolds number scaling study was not done for this aircraft model, the exact reason for this could not be determined. A further study, including Reynolds number and geometry scaling effects, is required if the flap-deflected data is to be incorporated into a flight simulation model.

The ice shapes had some measurable effects on control surface effectiveness, but mostly near stall. The effects of ice shapes on the rotational characteristics were not significant at pre-stall angles of attack. Most significant differences were observed in the stall regions in the rolling moment. The most significant effect of ice on the forced oscillation was measured in the rolling-moment coefficient due to roll rate near the stall angles of attack. The ice configurations had little effect on pitch and yaw damping values.

\section{References}

1. Ratvasky, T.P., Ranaudo, R.J., Barnhart, B.P., Dickes, E.G., and Gingras, D.R., "Development and Utility of a Piloted Flight Simulator for Icing Effects Training," 41 st AIAA Aerospace Sciences Meeting and Exhibit, Jan. 6-9, 2003, Reno, NV, AIAA Paper 2003-0022, NASA/TM-2003-212116.

2. Gingras, D.R., Dickes, E.G., Ratvasky, T.P., and Barnhart, B.P., "Modeling of In-Flight Icing Effects for Pilot Training," AIAA Modeling and Simulation Technologies Conference and Exhibit, Aug. 5-8, 2002, Monterey, CA, AIAA Paper 2002-4605.

3. Papadakis, M., Gile-Laflin, B.E., Youssef, G.M., and Ratvasky, T.P., “Aerodynamic Scaling Experiments With Simulated Ice Accretions," 39th AIAA Aerospace Sciences Meeting and Exhibits, Jan. 8-11, 2001, Reno, NV, AIAA Paper 2001-0833.

4. Lee, S., Barnhart, B.P., Ratvasky, T.P., Dickes, E.G., and Thacker, M., "Dynamic Wind Tunnel Testing of a Sub-Scale Iced Business Jet," 44th AIAA Aerospace Sciences Meeting and Exhibit, Jan. 9-12, 2006, Reno, NV, AIAA Paper 2006-0261, NASA/TM-2006-214268.

5. Lee, S., Ratvasky, T.P., Thacker, M., and Barnhart, B.P., "Geometry and Reynolds Number Scaling on an Iced Business Jet Wing," 43rd AIAA Aerospace Sciences Meeting and Exhibits, Jan. 10-13, 2005, Reno, NV, AIAA Paper 2005-1066, NASA/TM-2005-1066.

6. Ratvasky, T.P., Barnhart, B.P., Lee, S., and Cooper, J., "Flight Testing an Iced Business Jet for Flight Simulation Model Validation," 45th AIAA Aerospace Sciences Meeting and Exhibit, Jan. 8-11, 2007, Reno, NV, AIAA Paper 2007-0089, NASA/TM-2007-214936.

7. Bidwell, C.S., "Icing Analysis of the NASA S3 Icing Research Aircraft Using LEWICE3D Version 2," SAE Paper 07ICE137, Sept. 2007. 
8. Addy, H.E., Broeren, A.P., Zoeckler, J.G., and Lee, S., “A Wind Tunnel Study of Icing Effects on a Business Jet Airfoil," 41st AIAA Aerospace Science Meeting and Exhibit, Jan. 6-9, 2003, Reno, NV, AIAA Paper 2003-0727.

9. Broeren, A.P., Bragg, M.B., Addy, H.E., Lee, S., Moens, F., and Guffond, D., "Effect of HighFidelity Ice Accretion Simulation on the Performance of a Full-Scale Airfoil Model," 46th AIAA Aerospace Sciences Meeting and Exhibit, Jan. 7-10, 2008, Reno, NV, AIAA Paper 2008-0434. 



\begin{tabular}{|c|c|c|c|c|c|}
\hline \multicolumn{5}{|c|}{ REPORT DOCUMENTATION PAGE } & $\begin{array}{c}\text { Form Approved } \\
\text { OMB No. 0704-0188 }\end{array}$ \\
\hline \multicolumn{6}{|c|}{ 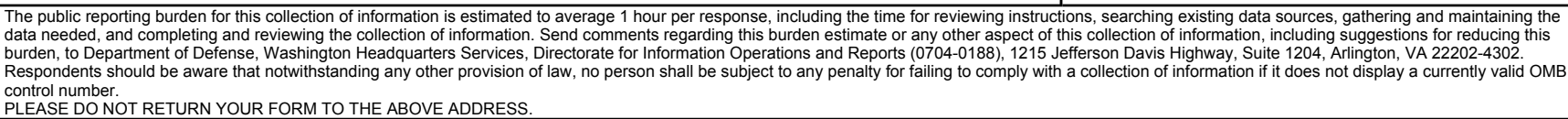 } \\
\hline \multicolumn{2}{|c|}{$\begin{array}{l}\text { 1. REPORT DATE (DD-MM-YYYY) } \\
01-09-2012\end{array}$} & \multicolumn{3}{|c|}{$\begin{array}{l}\text { 2. REPORT TYPE } \\
\text { Technical Memorandum }\end{array}$} & 3. DATES COVERED (From - To) \\
\hline \multirow{3}{*}{\multicolumn{5}{|c|}{$\begin{array}{l}\text { 4. TITLE AND SUBTITLE } \\
\text { Dynamic Wind-Tunnel Testing of a Sub-Scale Iced S-3B Viking }\end{array}$}} & 5a. CONTRACT NUMBER \\
\hline & & & & & 5b. GRANT NUMBER \\
\hline & & & & & 5c. PROGRAM ELEMENT NUMBER \\
\hline \multirow{3}{*}{\multicolumn{5}{|c|}{$\begin{array}{l}\text { 6. AUTHOR(S) } \\
\text { Lee, Sam; Barnhart, Billy; Ratvasky, Thomas, P. }\end{array}$}} & 5d. PROJECT NUMBER \\
\hline & & & & & 5e. TASK NUMBER \\
\hline & & & & & $\begin{array}{l}\text { 5f. WORK UNIT NUMBER } \\
\text { WBS 457280.02.07.03.02.02 }\end{array}$ \\
\hline \multicolumn{5}{|c|}{$\begin{array}{l}\text { 7. PERFORMING ORGANIZATION NAME(S) AND ADDRESS(ES) } \\
\text { National Aeronautics and Space Administration } \\
\text { John H. Glenn Research Center at Lewis Field } \\
\text { Cleveland, Ohio 44135-3191 }\end{array}$} & $\begin{array}{l}\text { 8. PERFORMING ORGANIZATION } \\
\text { REPORT NUMBER } \\
\text { E-18367 }\end{array}$ \\
\hline \multirow{2}{*}{\multicolumn{5}{|c|}{$\begin{array}{l}\text { 9. SPONSORING/MONITORING AGENCY NAME(S) AND ADDRESS(ES) } \\
\text { National Aeronautics and Space Administration } \\
\text { Washington, DC 20546-0001 }\end{array}$}} & $\begin{array}{l}\text { 10. SPONSORING/MONITOR'S } \\
\text { ACRONYM(S) } \\
\text { NASA }\end{array}$ \\
\hline & & & & & $\begin{array}{l}\text { 11. SPONSORING/MONITORING } \\
\text { REPORT NUMBER } \\
\text { NASA/TM-2012-217684 }\end{array}$ \\
\hline \multicolumn{6}{|c|}{$\begin{array}{l}\text { 12. DISTRIBUTION/AVAILABILITY STATEMENT } \\
\text { Unclassified-Unlimited } \\
\text { Subject Category: } 02 \\
\text { Available electronically at http://www.sti.nasa.gov } \\
\text { This publication is available from the NASA Center for AeroSpace Information, 443-757-5802 }\end{array}$} \\
\hline \multicolumn{6}{|c|}{ 13. SUPPLEMENTARY NOTES } \\
\hline \multirow{2}{*}{\multicolumn{6}{|c|}{$\begin{array}{l}\text { 14. ABSTRACT } \\
\text { The effect of ice accretion on a 1/12-scale complete aircraft model of S-3B Viking was studied in a rotary-balance wind tunnel. Two types } \\
\text { of ice accretions were considered: ice protection system failure shape and runback shapes that form downstream of the thermal ice } \\
\text { protection system. The results showed that the ice shapes altered the stall characteristics of the aircraft. The ice shapes also reduced the } \\
\text { control surface effectiveness, but mostly near the stall angle of attack. There were some discrepancies with the data with the flaps deflected } \\
\text { that were attributed to the low Reynolds number of the test. Rotational and forced-oscillation studies showed that the effects of ice were } \\
\text { mostly in the longitudinal forces, and the effects on the lateral forces were relatively minor. } \\
\text { 15. SUBJECT TERMS } \\
\text { Icing; Aerodynamics }\end{array}$}} \\
\hline & & & & & \\
\hline \multicolumn{3}{|c|}{ 16. SECURITY CLASSIFICATION OF: } & $\begin{array}{l}\text { 17. LIMITATION OF } \\
\text { ABSTRACT }\end{array}$ & $\begin{array}{l}\text { 18. NUMBER } \\
\text { OF }\end{array}$ & $\begin{array}{l}\text { 19a. NAME OF RESPONSIBLE PERSON } \\
\text { STI Help Desk (email:help@sti.nasa.gov) }\end{array}$ \\
\hline $\begin{array}{l}\text { a. REPORT } \\
\text { U }\end{array}$ & $\begin{array}{l}\text { b. ABSTRACT } \\
\text { U }\end{array}$ & $\begin{array}{l}\text { c. THIS } \\
\text { PAGE } \\
\text { U }\end{array}$ & UU & $\begin{array}{l}\text { PAGES } \\
20\end{array}$ & $\begin{array}{l}\text { 19b. TELEPHONE NUMBER (include area code) } \\
443-757-5802\end{array}$ \\
\hline
\end{tabular}



